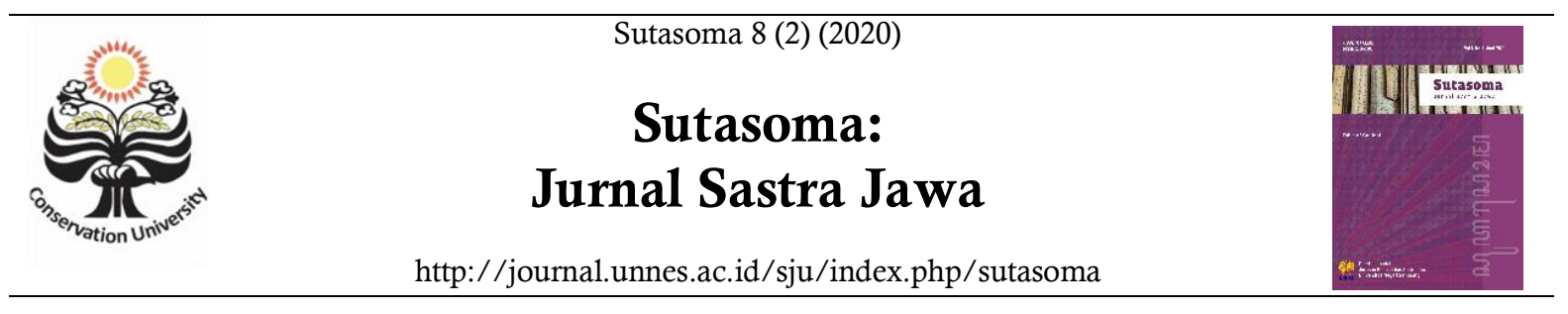

\title{
Gaya Bahasa dalam Singir (Syi'ir) Mutiara Isra' Mi'raj sebagai Puisi Jawa Tradisional
}

\author{
Arum Novalia Nurianti \\ Jurusan Bahasa dan Sastra Jawa, Fakultas Bahasa dan Seni, Universitas Negeri Semarang, Indonesia \\ Corresponding Author: arumnoval27@gmail.com
}

\begin{abstract}
Abstrak
Syi'ir merupakan salah satu karya sastra dan tergolong dalam puisi Jawa tradisional yang syarat akan beragam jenis gaya bahasa. Sebab itu, penelitian ini bertujuan untuk mengkaji (1) wujud gaya bahasa yang ada dalam Syi'ir Mutiara Isra' Mi'raj dan (2) fungsi gaya bahasa yang ada dalam Syi'ir Mutiara Isra' Mi'raj. Penelitian ini menggunakan metode deskriptif kualitatif. Teori yang digunakan menggunakan teori gaya bahasa Keraf dengan pendekatan stilistika milik Nurgiyantoro. Data dari penelitian ini berupa kata-kata, frasa, ataupun kalimat yang mengandung gaya bahasa. Sumber data dari penelitian ini berupa lirik-lirik dalam Syi'ir Mutiara Isra' Mi'raj. Pengumpulan data menggunakan metode dokumentasi dalam bentuk dokumen pribadi milik narasumber. Hasil penelitian ini menunjukkan bahwa ada enam gaya bahasa yang dominan beserta fungsinya dalam Syi'ir Mutiara Isra' Mi' raj meliputi; (1) gaya bahasa antonomasia dengan fungsi pemberian label dan ciri khas; (2) gaya bahasa anafora dengan fungsi penekanan; (3) gaya bahasa asonansi dengan fungsi keindahan bunyi; (4) gaya bahasa antitesis dengan fungsi membandingan dua hal berlawanan; (5) gaya bahasa anakuloton dengan fungsi mengkonsentrasikan makna dengan bahasa yang singkat; dan (6) gaya bahasa enumerasio dengan fungsi menghasilkan imaji.
\end{abstract}

Kata Kunci: gaya bahasa, singir Mutiara Isra' Mi'raj, puisi jawa

\begin{abstract}
Syi'ir is one of the literary works belonging to traditional Javanese poetry which requires a variety of language styles. Therefore, this research aims to examine (1) the form of language style that is in Syi'ir Mutiara Isra' Mi'raj and (2) the function of language style that is in Syi'ir Mutiara Isra' Mi'raj. The theory used is the Keraf language style theory with a stylistic approach from Nurgiyantoro. The data from this research in the form of the lyrics in Syi'ir Mutiara Isra' Mi'raj . Data collection uses the documentation method in the form of personal documents from informants. The results of this study indicate that there are six dominant language styles and their functions in Syi'ir Mutiara Isra' Mi'raj including; (1) antonomasia language style with labeling and characteristics function; (2) anaphora language style with emphasis function; (3) assonance language style with sound beauty function; (4) antithesis language style with the function of comparing two opposites; (5) anaculoton language style with the function of concentrating meaning in short language; and (6) enumeration language style with image generating function.
\end{abstract}

Keywords: language style, Singir Mutiara Isra' Mi'raj, javanese poetry

(C) 2020 Universitas Negeri Semarang

p-ISSN 2252-6307 


\section{PENDAHULUAN}

Puisi sebagai salah satu bentuk karya sastra merupakan hasil cipta dari seorang pengarang atau penyair dalam mengungkapkan berbagai ekspresi dengan mempertimbangkan bahasa yang indah dan penuh imajinasi (Prahutami 2014:88). Berdasarkan perkembangan zaman dari waktu ke waktu, puisi sendiri dibagi menjadi puisi lama yang syarat atau terikat akan aturan dan puisi baru yang sudah tidak terikat oleh aturan atau dapat dikatakan bebas. Dalam puisi Jawa terbagi atas puisi Jawa tradisional dan puisi Jawa modern.

Puisi Jawa tradisional sendiri ternyata tidak hanya dalam bentuk kakawin, kidung, dan tembang saja. Rahmawati (dalam Chamalah 2018:141) mengatakan bahwa syi'ir atau singir juga merupakan salah satu dari karya sastra puisi Jawa tradisional. Namun syi'ir sebagai salah satu karya sastra Jawa masih jarang diteliti, hal ini sejalan dengan ungkapan Ma'mun (2014:212) yang mengatakan bahwa syi'ir dapat dikatakan masih sedikit disentuh oleh peneliti lain dibandingkan dengan beberapa puisi tradisional lain, seperti kakawin, tembang macapat, geguritan, dan lain-lain.

Singir sendiri dalam penjelasan Rahmawati (2015:244) sebenarnya merupakan istilah dari kebiasaan pengucapan oleh masyarakat Jawa dalam mengucapkan kata syi'ir pada huruf Arab 'ain menjadi ngain. Kemudian oleh Abdullah (2012:158) menjelaskan bahwa sastra pesantren yang berkembang berada di daerah Jawa Pesisiran dengan salah satu karyanya berupa syi'ir. Sehingga singir atau syi'ir merupakan istilah lain dari syair, di mana syair itu sendiri merupakan puisi lama yang memiliki empat baris di setiap baitnya dengan rima yang sama dan berisikan cerita, nasihat, agama, dan lain-lain.

Karena syi'ir ini berkembang di Jawa khusunya sekitar pondok pesantren, masjid, maupun pengajian, maka bahasa yang digunakan dalam puisi tersebut adalah bahasa Jawa dengan tidak meninggalkan huruf Arabnya (Arab Pegon). Dari hal tersebut, syi'ir bukan tiba-tiba ada namun karena adanya perkembangan Islam yang masuk ke Indonesia, sehingga terjadilah perkawinan budaya antara Arab dengan Jawa khususnya pada karya sastra puisi (Ma'mun 2014:212).

Mussaif (2018:555) mengatakan bahwa syi'ir atau singir merupakan salah satu sastra puisi yang dapat dikatakan tidak dianggap sebagai sastra Jawa (kraton), karena terdapat beberapa perbedaan dengan sastra Jawa puisi pada umumnya yang terletak pada bahasa, huruf atau aksara, dan unsur estetika. Penjelasan lebih lanjut bahwa bahasanya dianggap menggunakan bahasa Jawa kasar, huruf atau aksaranya menggunakan akasara Arab, dan unsur estetikanya tida berpacu pada aturan sastra Jawa.

Berdasarka Pengalaman yang telah dialami peneliti, selain membaca Iqro' dan AlQur'an, hafalan Juz'ama dan sholat, belajar ilmu tajwid, ajaran taklim, dan doa sehari-hari, singir juga kerap kali dilantunkan bersama anak-anak yang mengaji di TPQ Al-Hidayah, Desa Punggelan, Kecamatan Punggelan, Kabupaten Banjarnegara. Sehingga dari hal tersebut menjadi tradisi dalam pondok 
pesantren, masjid-masjid maupun musholamushola saat bulan Ramadhan, dan dari dulu hingga sekarang masih diajarkan di TPQ AlHidayah. Maka dari itu, singir ini tergolong dalam puisi Jawa tradisional.

Peneliti bermaksud mengkaji salah satu dari koleksi syi'ir yang dimiliki TPQ tersebut, yaitu syi'ir dengan judul Singir Mutiara Isra' Mi'raj. Syi'ir ini memiliki bait sebanyak 12 (dua belas) bait, namun terdapat bait lain yang masuk dalam sub judul lain yang masih berkaitan dengan (judul utama) Singir Mutiara Isra' Mi'raj itu sendiri. Sub judul yang masih berkaitan dengan judul utama, yaitu (1) Tindak Wanci Dalu, (2) Pristiwa Isra'-Pelambang Wong kang Ngahirake Sholat, (3) Perlambang Wong kang Mangan Riba, (4) Perlambang Wong kang Ngrasani Ala, (5) Kanjeng Nabi Angganda Wangi, dan (6) Mi'raj.

Dari uraian di atas, alasan peneliti memilih untuk meneliti Syi'ir Mutiara Isra' Mi'raj karena: (1) masih belum banyak yang meneliti syi'ir, (2) syi'ir yang sering diteliti biasanya Syi'ir Tanpa Waton dan Syi'ir Ngudi Susila, dan (3) syi'ir merupakan bentuk puisi yang unik berbeda dengan puisi Jawa tradisional lain.

Syi'ir sebagai puisi khususnya puisi Jawa tradisional dalam karya sastra, pada intinya merupakan perwujudan ekspresi perasaan dari seorang penyair guna memberi kesan atau mempengaruhi perasaan pembaca. Ekspresi penyair tersebut terwujud dalam katakata yang mungkin tersirat oleh makna. Katakata dengan makna tersirat itulah yang sering disebut dengan gaya bahasa.
Dalam usaha untuk menemukan gaya bahasa, hal ini berhubungan erat dengan stilistika. Penggunaan kajian stilistika sendiri memberi kemudahan bagi peneliti untuk memahami ataupun memaknai apa yang sebenarnya ingin disampaikan pengarang kepada para pembacanya. Selain itu, penggunaan gaya bahasa juga tidak terlepas dari fungsinya. Karena gaya bahasa digunakan tidak hanya semata-mata untuk memperindah, namun juga memiliki peran atau fungsi yang lain sehingga membuat puisi atau syair itu sendiri indah.

Penelitian yang relevan dengan penelitian tentang syi'ir antara lain dalam penelitian yang dilakukan oleh": (1) Kusnadi (2006) berjudul "Seni Singiran dalam Ritual Tahlilan pada Masyarakat Islam Tradisional Jawa"; (2) Abdullah (2012) berjudul "Aspek Esoteris dalam Syi'ir Erang-Erang Sekar Panjang (Suatu Edukasi Etis dalam Sastra Pesantren)"; (3) Hamid (2017) berjudul "Elements Of The Arabian Syi'ir In The Qur'an's Structure"; dan peneliti lain. Penelitian yang berkaitan dengan gaya bahasa dalam syi'ir dengan pendekatan stilistika dilakukan oleh Fathoni (2012) berjudul "Gaya Bahasa Dalam Syi'ir "Al-i'tirāf" Karya Abu Nawas: Sebuah Analisis Stilistik". Penelitian yang berkaitan dengan Isra' Mi'raj dilakukan oleh Mutakin (2013) berjudul "Naskah Tentang Isra' Mi'raj dalam Bentuk Nadoman". Penelitian yang berkaitan dengan Puisi Jawa Tradisonal dilakukan oleh: (1) Waluyo (2013) berjudul "The Development of Modern Javanese Poetry and Javanese Tembang for The Linguistic 
Education Program: Sociology of Literature Approach"; (2) Heriwati (2017) berjudul "Imperative Speech Acts in Javanese Songs". Berdasarkan penelitian-penelitian yang telah dilakukan, belumada yang mengkaji mengenai gaya bahasa dalam syi'ir yang berjudul Singir Mutiara Isra' Mi'raj sebagai puisi Jawa tradisional dengan pendekatan stilistika.

\section{METODE PENELITIAN}

Desain penelitian ini menggunakan penelitian deskriptif kualitatif dari teori Moloeng (2010:6) berpendapat bahwa penelitian deskriptif kualitatif merupakan penelitian yang bertujuan untuk mendeskripsikan pemahaman tentang suatu fenomena dari subjek yang diteliti secara utuh dengan menggunkan metode ilmiah. Data dan Sumber data yang akan dilakukan dalam penelitian ini diperoleh dari naskah Syi'ir Mutiara Isra' Mi'raj berbentuk buku yang ditulis menggunakan huruf Arab pegon. Instrumen penelitian ini adalah peneliti itu sendiri dengan dibantu tabel klasifikasi. Metode pengumpulan data penelitian ini menggunakan metode dokumentasi, metode simat, dan metode catat. Metode analisis data yang digunakan yaitu metode deskriptif kualitatif dengan pendekatan stilistika.

\section{HASIL DAN PEMBAHASAN}

Analisis gaya bahasa ini menggunakan teori dari Keraf (2006 112-145 yang membagi gaya bahasa menjadi tiga kelompok besar yakni: (1) gaya bahasa berdasarkan struktur kalimat; (2) gaya bahasa berdasarkan langsung tidaknya makna yang dibagi lagi menjadi dua, yakni: (a) gaya bahasa retoris, dan (b) gaya bahasa kiasan. Dari ketiga kelompok besar tersebut, ditemukan enam gaya bahasa yang dominan dalam Syi'ir Mutiara Isra' Mi'raj beserta fungsinya.

\section{Gaya Bahasa Antonomasia}

Terdapat 31 gaya bahasa antonomasia dari 42 bait yang dianalisis. Jenis gaya bahasa antonomasia merupakan gaya bahasa kiasan yang menggantikan nama atau sebutan pada sesuatu dengan sifat yang melekat dengan gelar atau jabatan. Contohnya dalam kutipan syi'ir ini yaitu:

Tugas perintah Kang Maha Suci

Gusti Njeng Nabi pinuju sare

Kata Kang Maha Suci mengganti sebutan Allah/ Tuhan dengan kata sifat dan kata Gusti Njeng Nabi mengganti nama Muhammad dengan gelar nabi yang diberikan Allah yang merupakan pemimpin para ummatnya. Fungsi gaya bahasanya adalah memberikan label dan ciri khas sehingga terkesan tidak monoton dalam menyebut satu nama.

\section{Gaya Bahasa Anafora}

Terdapat 6 gaya bahasa antonomasia dari 42 bait yang dianalisis. Jenis gaya bahasa anafora merupakan gaya bahasa berdasarkan struktur kalimat yang mengulang kata, frasa, atau klausa pada awal kalimat. Contohnya salah satu dalam kutipan syi'ir ini yaitu:

\section{Kang nggawe langit sarta bumine}

Kang welas asih ing kawulane 
Kata Kang diulang-ulang di bagian awal kalimat. Fungsi gaya bahasanya adalah memberi penekanan sehingga terkesan lebih tegas dalam menjelaskan suatu ungkapan.

\section{Gaya Bahasa Asonansi}

Terdapat 7 gaya bahasa asonansi dari 42 bait yang dianalisis. Jenis gaya bahasa asonansi merupakan gaya bahasa retoris yang mengulang bunyi vokal dalam suatu kalimat atau baris. Contohnya dalam kutipan syi'ir ini yaitu:

Ngawiti ingsun iki singiran

Kadiya mutiara kang endah

Dari kutipan di atas, terdapat bunyi vokal $i$ dan $a$ yang diulang-ulang dalam satu baris masing-masing. Fungsi gaya bahasanya adalah memberi keindahan bunyi sehingga terlihat lebih estetis dan lembut secara nada.

\section{Gaya Bahasa Antitesis}

Terdapat 16 gaya bahasa asonansi dari 42 bait yang dianalisis. Jenis gaya bahasa antitesis merupakan gaya bahasa berdasarkan struktur kalimat dimana terdapat dua kata saling bersandingan namun saling berlawanan arti. Contohnya dalam kutipan syi'ir ini yaitu:

\section{Isra' lan mi'raj kudu dirumat}

Muga selamet dunya akhirat

\section{Kata Isra' lan Mi'raj merupakan} pasangan kata yang artinya menyimpang di mana isra' adalah peristiwa perjalanan malam hari Nabi Muhammad menuju langit ke tujuh, sedangkan mi'raj adalah peristiwa di mana Nabi Muhammad menerima perintah untuk menunaikan sholat bersama ummatnya. Dan kata dunya akhirat merupakan pasangan kata yang artinya berlawanan antara bumi yang berada lebih rendah dari akhirat atau langit ketujuh. Fungsi gaya bahasanya adalah memberi perbandingan dua hal yang berlawanan sehingga lebih terasa maknanya dan terlihat emosional.

\section{Gaya Bahasa Anakuloton}

Terdapat 29 gaya bahasa anakuloton dari 42 bait yang dianalisis. Jenis gaya bahasa anakuloton merupakan gaya bahasa kiasan di mana terdapat suatu kata tidak baku namun masih tetap lumrah digunakan pada karya sastra. Contohnya salah satu dalam kutipan syi'ir ini yaitu:

Ing wektu iku Njeng Nabi sare

Kata Njeng merupakan bentuk kata yang tidak baku namun masih berkaitan dan mempunyai makna yang sama dengan kata kanjeng yang berarti memiliki kedudukan tinggi dan terhormat. Fungsi gaya bahasanya adalah mengkonsentrasikan makna dengan bahasa yang singkat sehingga terlihat lebih tepat guna sesuai aturan suku kata pada syi'ir tersebut.

\section{Gaya Bahasa Enumerasio}

Terdapat 14 gaya bahasa anakuloton dari 42 bait yang dianalisis. Jenis gaya bahasa enumerasio merupakan gaya bahasa kiasan di mana dalam suatu kalimat atau suatu bahasan dijabarkan dengan rinci dan menyeluruh. Contohnya salah satu dalam kutipan syi'ir ini yaitu:

Tindak Njeng Nabi kendel Madinah

Perlu nindakke ngamal ngibadah 


\section{Nglampahi sunat kalih reka'at}

Amuji syukur marang Pengeran

Kutipan di atas menunjukkan bahwa bait tersebut menjelaskan suatu keadaan dengan detail yaitu di tengah perjalanan Nabi berhenti sejenak untuk menunaikan sholat Sunnah yang terdiri dari dua rakaat yang bertujuan untuk mensyukuri segalanya pada Tuhan. Fungsi gaya bahasanya adalah menghasilkan imaji sehingga terlihat lebih rinci dan runtut.

\section{PENUTUP}

\section{Simpulan}

Berdasarkan hasil analisis, wujud gaya bahasa yang dominan pada naskah dalam Syi'ir Mutiara Isra' Mi'raj ada 6, yaitu meliputi: (1) antonomasia yang termasuk dalam gaya bahasa kiasan; (2) anafora yang termasuk dalam gaya bahasa berdasarkan struktur kalimat; (3) asonansi yang termasuk dalam gaya bahasa retoris; (4) antitesis yang termasuk dalam gaya bahasa berdasarkan struktur kalimat; (5) anakuloton yang termasuk dalam gaya bahasa kiasan; dan (6) enumerasio yang termasuk dalam gaya bahasa kiasan.

Fungsi gaya bahasa yang terdapat pada naskah dalam Syi'ir Mutiara Isra' Mi'raj antara lain: (1) fungsi pemberian label dan ciri khas pada gaya bahasa antonomasia; (2) fungsi penekanan pada gaya bahasa anafora; (3) fungsi keindahan bunyi pada gaya bahasa asonansi; (4) fungsi memperbandingkan dua hal berlawanan pada gaya bahasa antitesis; (5) fungsi pengkonsentrasian makna dengan bahasa yang singkat pada gaya bahasa anakuloton; dan (6) fungsi menghasilkan imaji pada gaya bahasa enumerasio.

\section{Saran}

Dari hasil penelitian ini diharapkan dapat memperkaya berbagai macam gaya bahasa yang mungkin saat duduk dibangku sekolah jarang ditemukan. Serta dapat memberi makna yang menyeluruh mengenai gaya bahasa, sehingga dapat menambah khasanah ilmu terutama pada ilmu stilistika.

Penelitian ini tergolong sedikit yang berminat untuk melakukan penelitian tentang syi'ir khususnya Syi'ir Mutiara Isra' Mi'raj. Sehingga, perlu adanya penelitian lebih lanjut terhadap syi'ir khususnya Syi'ir Mutiara Isra' Mi'raj.

\section{DAFTAR PUSTAKA}

Abdullah M. 2012. Aspek Esoteris dalam Syi'ir Erang-Erang Sekar Panjang (Suatu Edukasi Etis dalam Sastra Pesantren). Jurnal Humanika, Vol. 15, 158-167.

Chamalah, E dkk. 2018. Local Literature in Coastal Pesantren as an Alternative on Literary Reading Subject for Students of PBSI Unissula. Advances in Social Science, Education and Humanities Research (ASSEHR), Volume 247, 141-144.

Fathoni, H. 2012. Gaya Bahasa Dalam Syi'ir "Ali'tirāf" Karya Abu Nawas: Sebuah Analisis Stilistik. Jurnal At-Ta'dib, Vol. 7 No.2, 205224.

Hamid, M. 2017. Elements Of The Arabian Syi'ir In The Qur'an's Structure. International Journal of Scientific \& Technology Research, Vol. 6 Issue 6, 109-113.

Heriwati, S.H. 2017. Imperative Speech Acts in Javanese Songs. International Journal of Science and Research (IJSR), Vol. 6 Issue 8, 226-237.

Keraf, G. 2006. Diksi dan Gaya Bahasa. Jakarta: Gramedia Pustaka Umum.

Kusnadi. 2006. Seni Singiran dalam Ritual Tahlilan pada Masyarakat Islam Tradisional Jawa. Imaji, Vol. 4 No. 2, 218-231.

Ma'mun, T.N. 2014. Pengaruh Syair Arab terhadap Pola Syi'iran di Jawa Barat. Panggung, Vol. 24 No.3, 211-223. 
Arum Novalia Nurianti./Sutasoma 8 (2) (2020)

Moloeng, L.J. 2010. Metodologi Penelitian Kualitatif. Bandung: Remaja Rosdakarya.

Mussaif, M.M. 2018. Kedudukan dan Fungsi Singir Sebagai Sastra Jawa Pesisir Kajian Genre dan Sosiologi. NUSA, Vol. 13 No. 4, 554566.

Mutakin. 2013. Naskah Tentang Isra' Mi'raj dalam Bentuk Nadoman. Jurnal Lektur Keagamaan, Vol. 11, No. 1, 223-236.

Prahutami, N. 2014. Kajian Stilistika pada Kumpulan Geguritan Bojonegoro Ing Gurit Himpunan Sanggar Sastra Pamarsudi Basa Jawi Bojonegoro. Jurnal Program Studi Pendidikan Bahasa dan Sastra Jawa_Universitas Muhammadiyah Purworejo, Vol. 04 / No. 04, 88-93.

Rahmawati, S. 2015. Ajaran Islam dalam NaskahNaskah Singir Koleksi Fsui sebagai Bentuk Persinggungan Budaya Islam-Jawa: Kajian Intertekstualitas. Al-Turäs, Vol. XXI, No.2, 243-254.

Waluyo, H.J dkk. 2013. The Development of Modern Javanese Poetry and Javanese Tembang for The Linguistic Education Program: Sociology of Literature Approach. Asian Journal of Social Sciences \& Humanities, Vol. 2 No.3, 34-39. 